\title{
3 Layered rhetorics and multiple realities
}

\author{
China and Africa
}

\section{Julia C. Strauss}

\section{Introduction}

One of the most common questions about the burgeoning complex of relationships between China and Africa is one of radical simplification: what is China doing in Africa? The immediate if often unstated corollary that often follows is: what are China's intentions in (doing whatever it is doing) Africa? These questions, repeated endlessly in Western press and by Western policy-making think tanks, may reveal far more about the structure of Western press and the preoccupations of Western policy-makers than they do about China, Africa, or the increasingly complex and multilayered set of interactions between the two. Rather than focusing on one element, sector, or specific bilateral relationship, this chapter proposes a broad view that takes seriously what 'official China' (government organizations, state-owned enterprises, and their spokespeople) have claimed its intentions in Africa to be, and then engages in brief excursion into the range of African voices that respond to both these intentions and the inevitable gaps between intention and reality. In so doing, this chapter draws on and updates my earlier work on China's official rhetoric for Africa (Strauss 2009) and the extension of the rhetoric to Latin America several years later (Strauss 2012).

To reiterate the caveats first articulated 7 and nearly 10 years ago, I do not suggest by any means that China's self-image as a development actor, or its rhetoric in support of its developmental claims are somehow 'true,' or that they do not need to be treated skeptically in the light of real-life action. I suggest only that the gap between most states' official claims (whether to benevolence, democracy, human rights, or to 'win-win' development) and their actions is often quite large, and that the Chinese state is no more or less devious than any other state if it seeks to explain its motivations and activities in the best possible light. Insofar as one can separate claims from reality, with all the slippage and legitimate different interpretations that come into play that engaging in critical analysis inevitably entails, paying attention to the rhetoric makes it possible to 
understand the broad framing, the basic assumptions, and also the pitch that the entity we call 'China' is making to the entity we call 'Africa.' How different African actors respond to the rhetoric - and its inevitable departure from realit(ies) - is surely more important than how Western press and think tanks respond to the same rhetoric and departures from realit(ies), but that does not mean that Western press, think tanks, and academia are absolved from making the effort. This chapter suggests that China's official rhetoric seldom, if ever, actively repudiates earlier iterations. Rather, as time goes on and circumstances dictate different responses to new questions, layers of rhetoric accrete without ever fully fading away. While typically the newest overlays of official rhetoric are what is most visibly deployed in response to the policy concerns of the moment, older, more foundational components of official rhetoric can be and are revealed either in response to a crisis, sometimes supporting and on other occasions in uneasy juxtaposition with the new. For their part, the African voices that respond to China are multi-vocal, varying by country, sector, and specific immediate context.

All states make grand claims about the principles and rightness of their international actions that are often contradicted by reality: the United States' historic claims to be a beacon of democracy and its support for human rights are frequently belied by its realpolitik support for authoritarian and often brutal regimes. China's rhetorical justification and claims are different, but also generate interesting tensions and contradictions. China claims solidarity and fraternity with Africa, but now stands accused of putting key countries - including those in Africa such as Kenya and Djibouti - into 'debt traps' (Peralta 2018). It continues to distinguish its approach to development as untainted by colonialism and hegemonism, but in 2017 the China Merchant Ports Holding Company took a 70 percent stake and a 99-year lease on the Hambantota Port in Sri Lanka when the government could not pay back the loans it had taken out. Sri Lanka is not a stand in for Africa, but the China Merchant Ports Holding Company's precedent shattering takeover of the Habantota Port must raise concerns for heavily indebted countries in Africa, and, for those who know their history, a 99-year lease on the port is exactly what was imposed on China with the 99-year lease of the New Territories in Hong Kong - a marker of colonially imposed national humiliation until Hong Kong's retrocession to China in 1997. China insists on noninterference and respect for sovereignty, but has come to play an increasingly interventionist role in 
Sudan and South Sudan, most clearly in 2008, when it responded to the Darfur crisis by playing a large role in organizing peacekeeping by the United Nations and when it established a consulate in Juba in anticipation of the independence of South Sudan, where it continues its attempts to ensure security for its personnel and broker agreements between the warring factions (ICG 2017). For all, events and national interests often, even typically undermine principled rhetoric. But that does not mean that the rhetoric is meaningless, or that the rhetoric might not contain its own internal tensions and contradictions.

\section{The foundational rhetoric of "Five" + "Eight": thirteen principles for imagined solidarity and replication}

Chinese official rhetoric on its foreign relations with the developing world has as its foundation two sets of principles it claims to be unchanging and eternal. The first of these is the set of the Five Principles of Peaceful Co-existence. Almost as old as the People's Republic of China (PRC) itself, they were formulated in 1954, when the PRC was militarily secure, had just fought the world's superpower to a standstill in Korea, and was domestically strong in pushing through its programs of revolutionary transformation. It was against a background of relative strength and regional security that the young PRC negotiated this agreement with Nehru government in India as a way of dampening down tensions between China and India over their contested border in the Himalayas. ${ }^{1}$ The Five Principles were a product of its time and circumstances: two large Asian states emerging from (semi-) colonialism with a strong desire to secure their borders and establish their national sovereignty, but also pitched to be broadly acceptable to other developing nations as a wider non-aligned movement gathered pace, culminating in the Bandung Conference of April, 1955. As such the Five Principles perfectly replicated the standards of a post-Westphalian state with a soupçon of Wilsonian pacifist idealism: the supreme sanctity of territorial integrity and state sovereignty, mutual non-aggression, mutual noninterference in domestic affairs, equality and mutual benefit, and peaceful coexistence.

The Eight Principles for Foreign and Economic Aid were announced some 10 years later, when then Premier Zhou Enlai was on a multi-country tour to Africa in 
January 1964. This timing also coincided with a period of relative moderation, as China sought to recover from the mass starvation that resulted from the Great Leap Forward of the late 1950s and early 1960s. In this iteration of eternal principles, revolutionary China went further in staking out its claim to be different and presumptively better than its then rivals - the West and the Soviet Union - in the way it approached aid and assistance to other developing countries. The Eight Principles stressed equality, mutual benefit rather than aid, the repudiation of conditionality and strict respect for sovereignty, reduction of crippling indebtedness through low-interest loans, no interest loans, rescheduling of loan repayments when necessary, and, critically, the goal of helping recipient countries to become self-reliant (Zhou 1964). Not unlike the Five Principles of Peaceful Co-existence, the Eight Principles failed its immediate acid test: not only was China's bid to lead the non-aligned movement at Bandung the following year unsuccessful, only a year after that the PRC was itself consumed by the domestic conflagration of the Cultural Revolution.

Given how each of these sets of presumptively unchanging principles failed to accomplish its immediate and medium term goals and were developed in a revolutionary, mobilizational context that has all but been repudiated by the developmentalist authoritarianism of the Chinese party-state since 1980, it is worth asking why these two, such old texts continue to exert such power. There are, I suspect, two answers to this question. First, educated Chinese elites - including political elites are deeply attached to history, and the further a foundational principle can be pushed back into the past, the more legitimating resonance it has in the present. ${ }^{2}$ But second, and more importantly, the Five Principles (of Coexistence) in combination with the Eight Principles (for Foreign and Economic Aid) reflect Chinese norms and practices emblematic of the Mao period that are still at the beating heart of what Chinese political and business elites imagine to be at the core of their own success: nationalist developmentalism, self-reliance, and a fierce dedication to what C. K. Lee labels 'collective asceticism' through the trope of 'eating bitterness' (chi ku 吃苦) (Lee 2018).

Taken together, the Five and the Eight reflect a world view of China's place in the world and of development in general that can claim to be different from and better than its competitors - the West (and, after the late 1950s, the 'revisionist' Soviet Union): 'we - like developing countries in Africa - are ourselves a developing country itself 
untainted by colonialism, principled in our distaste for moralistic name calling and inappropriately imposed conditionalities.' In addition, the Five and the Eight together are predicated on ideals of development and self-reliance that are in turn based on what I call 'modified fractal replication.' Drawing from mathematical notions, the fractal is a fundamentally self-replicating model or shape that is 'self-similar across different scales ... made by repeating a similar process' (The Fractal Foundation n.d.). As applied to China and Africa, this modality of modified fractal replication relies on a profoundly Maoist set of ideas: that development requires hard work, struggle, collective sacrifice, and the self-reliance of the unit in question. In Mao's own words, 'On what basis should our policies rest? It should rest on our own strength, and that means regeneration through our own efforts. We are not alone ... nevertheless we stress regeneration through our own efforts' (Mao 1945). Within China under Mao, the unit of self-reliance in daily life was the work unit, the collective, or the commune. But for the central economic plan it was a geographical unit (the county, city, or province depending on what level of the plan was under consideration), each of which was to fulfil its part in the plan on the basis of local materials and local initiative. And like the countries of Africa (or the countries of the developing world more generally), different regions within China whether at the provincial, county, or municipal levels - varied dramatically in size, positionality, natural resource endowments, education of the population, climate, and so on. Thus, despite the obvious differences between Africa and revolutionary China (Africa was clearly not part of a unitary state that insisted on a central economic plan), and within Africa itself, the Mao era insistence on self-reliance simply exported what already made sense within China (replication of centrally mandated models on the basis of self-reliance and local adaptation), to foreign environments. Thus from the mid-1950s onward, the revolutionary Chinese state's overtures to the developing world were predicated on both an imagined commonality and ideologically inflected notions of what worked well domestically within China itself: 'we, China, are a country that stood up to the imperialist West, developed only somewhat before you, and present a model that you can adapt in the light of your own circumstances. In the distant past, our ships came with Zheng He to make contact and trade, after which we left, unlike the Western powers that came and stayed to exploit; we understand you and your challenges because we have suffered from underdevelopment, poverty, and the indignities of a colonial West, 
too. Our technicians do not live in remote compounds, we live plainly and simply, and we work and sweat outside with you.'

\section{The second layer: from imagined commonality to globalized division of labor and comparative advantage}

From the 1980s to the present, the post-Mao reform era has sharply reversed the Chinese state's autarchic and egalitarian approach to its domestic development. While initially keeping the central plan, it brought in domestic markets, decollectivized agriculture, tolerated concentrations of wealth generation in already favored areas on the grounds that it was permissible for some to get rich faster than others and established incentives for local cadres to prioritize economic growth. It also, critically for the model of its relations with Africa, invited in foreign direct investment as a way of rapidly catching up with other rapid developers in East Asia in terms of technology transfer, shifted to globalization on the basis of specialization and comparative advantage, and quashed political dissent and social organizations it could not directly control in order to maintain 'stability' - as evidenced by the continuation of single-party rule. These policies, enacted piecemeal over the course of the next 30 years, ushered in an explosion of corruption and environmental damage, but equally did succeed in raising incomes, sustained and very high rates of growth of the gross domestic product (GDP) averaging 10 percent a year in the 1990s and 2000s, and lifted hundreds of millions out of absolute poverty (Riskin 2004; Baidu Baike 2019). The Chinese Communist Party (CCP) is, not unreasonably, proud of its role in presiding over China's leap up into the ranks of middle-income countries, reduction of poverty, and displays of shiny 'advanced' modernity through high-speed rail networks, skyscrapers, and big dams.

It is not surprising that when it turned back to engagement with Africa in the early 2000s, China's official rhetorics of engagement would feature exactly those elements that its state elites themselves consider so fundamental to its success: hard work in a globalized context of division of labor that ultimately benefits everyone to best pursue development. The older fractal logic of commonality and fraternity still continues to frame the preambles to high-level official pronouncements: China’s First African Policy Paper of 2006 opines that 'Sharing similar historical experience, China and Africa have 
all along sympathized with and supported each other in the struggle for national liberation and forged a profound friendship' (State Council 2006) - a statement that would not have been out of place in 1956 or 1976. The African Policy Paper of 2006, and all summits of the Forum on China-Africa Cooperation (FOCAC) from 2002 onward also open by noting that China is the largest developing country in the world and Africa is the continent with the largest number of developing countries. This otherwise unremarkable statement is by itself ambiguous in its nods to both old and newer rhetorics: does it suggest that China provides a model for the many African developing states to emulate and adapt to suit (the old fractal logic), or that China (one unitary state) and Africa (many smaller states) are complementary by virtue of different geographical scales and different stages of development?

Other official content makes clear that the currently energizing developmental logic is one of complementarity. Take, for example, this telling quote from FOCAC 2002 by Zhu Rongji:

Africa, on the one hand, boasts talented and hard-working people, abundant in natural resources, and great market and development potentials [sic]. China, on the other hand, has got considerable economic strength, a promising market and a wealth of commodities, managerial expertise and production technologies suitable for African countries.

(Zhu 2002)

Thus, when China began its serious re-engagement with Africa in the late 1990s and early 2000s, its rhetoric stressed how the complementary differences of Africa (lots of people, natural resources, market and development potential) fit like hand and glove with China's more advanced economic strength, promising market, commodities, expertise, and technology. Zhu does not explicitly frame the China-Africa relationship as one of 'win-win,' buttressed by resource-backed loans structured to ensure 'giving and getting' but the logic of complementarity in a globalized division of labor certainly lays the necessary groundwork for so doing. Other official pronouncements are more open about this logic. In the African Policy Paper 'China will establish and develop a new type of strategic partnership with Africa which features political equality and mutual trust, economic win-win [jingji gongying] cooperation and cultural exchange' 
(State Council 2006, italics added). It is important to point out that the original Chinese 'gongying' (共贏) is invariably slightly mistranslated into English as ‘win-win' - a locution with an explicitly transactional, often American business dealing inflected tone. 'Gongying' in Chinese is more collaborative and collective in connotation, meaning literally 'common winning' or 'winning in common.' Nevertheless, 'gongying' is nearly always paired with either grand pronouncement or as a legitimating principle for business deals between Chinese entities, typically state-owned enterprises (SOEs), and African governments that is dependent on globalized economic complementarity. This fundamental update of older fractal notions of replication and adaptation based on essential sameness still adheres to one of the core Five Principles - that of political equality and mutual benefit, now in practice reframed as the equality of states to decide which contracts they wish to make and loans they wish to take out in a globalized world of trade for profit.

Needless to say, there are any number of practical problems with China's upbeat and continually reiterated slogan of economic 'win-win.' In aggregate, Africa may well have 'won' more than China over the past two decades of increased trade and deal making. As Table 3.1 makes clear, in only 6 of the 15 years between 2002 and 2017 were Chinese exports to Africa greater than its imports from Africa, and in three of those years (2002, 2003, and 2009) the gaps between imports and exports were very small.

TAKE IN TABLE 3.1 (Figure 3.1)

Aggregate numbers, however, often gloss more than they reveal. Trade between China and Africa - as well as between China and the rest of the developing world - is often deeply and problematically skewed by country and by sector. The simplifying but not inaccurate slogan of 'win-win' begs a series of important political as well as economic questions: who wins, over what kind of time scale, and with what consequences that are not included in what is being measured? Are the winners African consumers, who benefit from lower prices on consumer goods? African political elites and their networks, who now have additional resources to tap? Chinese SOEs, for whom tied infrastructure deals guarantee profit? Resource-rich African states (Angola, the Democratic Republic of Congo, Nigeria, South Sudan) rather than resource-poor ones 
(Malawi, Chad, Senegal), or those sitting on prime real estate (Djibouti) rather than those that are landlocked (Malawi, the Central African Republic)? Those with important historic and public relationships with China (Tanzania, Zambia, Sudan, Ethiopia, Zimbabwe) rather than those of relative historical unimportance (Malawi, Chad, Madagascar)? Given a historic pattern of trade of African raw materials and commodities in exchange for either investment in infrastructure or the import of cheap consumer goods, is 'win-win' something that only obtains when the prices for commodities are relatively high, only to crash when prices for commodities decline, as they inevitably do in response to either oversupply or reduced demand ${ }^{3}$ And what about the potential mismatch of different sectors across different temporal scales? A win in investment, roads built, increase in GDP, cushion against future rises in commodity prices may well be another's loss in terms of forced sale of land or timber over which communities had customary right of use, medium term environmental degradation, or interest repayments that cannot be met. A win in terms of profit may come at the cost of labor rights, casualization, and bad local publicity. These considerations are, of course, elided in the smooth rhetoric of 'win-win,' but they are very much a part of what Chinese diplomats, SOEs, and managers deal with every day in Africa.

\section{The third layer: from 'win-win' to common development}

Perhaps in implicit recognition of the limitations suggested by the transactional language of 'economic win-win,' China's official rhetoric on China and Africa quickly came to add to 'win-win' the softening ideal of 'common development' (gongtong fazhan), without, however, jettisoning its fundamental commitment to the pursuit of comparative advantage in a globalized division of labor. In the Second Africa Policy Paper (China Daily 2015), the presumptions of formal equality, friendship, and complementarity for development are as pronounced as they ever were.

Over the past five decades and more, they [China and Africa] have always been good friends who stand together through thick and thin, good partners who share weal and woe, and good brothers who fully trust each other despite changes in the international landscape ... The development strategies of China and Africa are highly compatible. Given their respective strengths, 
China and Africa need each other for cooperation and development. Rare historic opportunities for mutually beneficial cooperation and common development have emerged. China's comparative advantages in development experience, applied technology, funds and market can help Africa overcome the two major bottlenecks constraining its development - backward infrastructure and inadequate professional and skilled personnel. They can also help Africa translate its natural and human resources advantages and potential into a driving force for development and benefits for people's livelihoods, thereby speeding up industrialization and agricultural modernization, and doing a better job in pursuing economic independence as well as self-reliant and sustainable development and achieving lasting peace and stability.

(China Daily 2015, italics added)

Let us consider this paragraph. Even when one factors in that such broad policy statements on important topics are invariably written by committee, as recently as 2015 , the official updated paper on China's Africa strategy displays elements of each of these three layers of China's rhetoric on Africa. The foundational base of amity and friendship, predicated on Mao-era notions of economic independence and self-reliance (the fractal based on a commonality that is gendered), is prominent. The paper reiterates China's principles of noninterference and respect for sovereignty that stand in implicit contrast to the West:

China respects African countries' independent choice of the way to development ... China has always sincerely supported Africa's development. It never interferes in African countries' internal affairs, never imposes its will on them, and attaches no political strings when providing aid to Africa.

(China Daily 2015)

The Second Africa Policy Paper then goes on to stress the second rhetorical layer of 'win-win' predicated on ideals of China's comparative advantage; complementarity and mutual benefit between China and Africa, now with nods to the more inclusive language of common development and, sustainable development. 
The core principle is to connect assistance to developing countries, including those in Africa, for their independent and sustainable development with China's own development, achieve win-win cooperation and common development, and promote more balanced, inclusive and sustainable development of the world at large.

(China Daily 2015)

The third section of the Africa Policy Paper explicitly points to what China means by ‘deepening economic and trade cooperation’:

- investing in Africa's industrialization 'to promote industrial alignment and capacity cooperation between China and African countries in an orderly fashion' (China Daily 2015);

- boosting Africa's agricultural modernization;

- $\quad$ participating in Africa's infrastructure modernization;

- $\quad$ strengthening China-Africa financial cooperation;

- $\quad$ promoting China-Africa trade and investment;

- bolstering resource and energy cooperation;

- expanding cooperating on the marine economy.

While this laundry list of aspirational promises is unlikely to ever be met in full, the list is itself important for what it reflects about China's ideals in terms of China-Africa policy (and indeed policy towards the developing world more generally): exporting much of China's own domestic experiences of the distant and recent past in promoting state investment into market based high-speed growth. In the Africa Policy Paper vision, China's support for Africa's industrialization means promoting special economic zones (SEZs), industrial parks, and science and technology parks: one of China's first departures from the Maoist autarkic economy was to promote foreign direct investment through SEZs. Agricultural modernization through the application of scientific techniques predates the establishment of the PRC and has been a constant in China's domestic development ever since. The stress on infrastructure mirrors China's own domestic growth (and current problems with excess capacity) - directly attributable to campaign style state investment in infrastructural projects: roads, high-speed rail, port development, airports, and telecommunications. Investment in and production of green 
technology such as solar and wind energy have made China the world's top exporter of clean energy (Buckley et al. 2018).

More recently still, the Beijing Declaration, that opened the FOCAC in Beijing in September 2018 (FOCAC 2018) imagines China and Africa as a joint community through continued 'common winning,' now backed up by China's pledge to invest another US\$60 billion in key priority areas, now including such new frontiers as connectivity, capacity-building, and peace and security, as well as returning to one of China’s previous strengths in Africa - health care (Xi 2018).

\section{The outer wrapper: the Belt and Road Initiative and attempted recentering}

The most recent, and most remarked upon, layer of China's formal rhetoric on Africa (and its outward-bound development policy more generally) is the enormous publicity given to what is now known as the Belt and Road Initiative (BRI). Previously translated directly and accurately into English from the Chinese 'yidai yilu’ (一帶一路) and accurately as 'One Belt-One Road' (OBOR), the BRI is a mega-strategy for the comprehensive export of China's distinctive approach to external development: complete upgrading of hard and soft infrastructure (roads, ports, railroads, energy generation, and communications) for the facilitation of trade and local development from China, softened by the organizing concepts of policy coordination, facilities connectivity, unimpeded trade, financial integration, and people-to-people bonds.

The original formulation for BRI consisted of land routes through Central Asia to Europe and South to Pakistan, and overseas through a 'string of pearls'; building and upgrading ports from the South China Sea through to Venice. Launched in 2013, the sheer scale of BRI - with amounts notionally pledged in the trillions to seventy-one states accounting for more than half the world's population - would by itself attract enormous attention from investors and foreign policy analysts. Much is rhetorically claimed for BRI. As a Xi Jinping-mandated signature policy that is important enough to have been enshrined in the CCP's most recent constitution in 2017, BRI is a profoundly political project domestically in China as it stakes part of Xi's legitimacy on its success thus setting up powerful incentives for officials to rapidly conclude deals that can be 
trumpeted as successful. But the contours of BRI are unclear in two major respects. First, there has been ambiguity in the ideational and conceptual construction of BRI. Originally conceived as an economic belt across Eurasia and a (Maritime Silk) Road across the Pacific and Indian Oceans up through the Red Sea towards Suez and Europe, BRI is now beginning to be promoted with a very different imaginary, a fundamentally global reach of 'wings' to the East (Latin America) and West (Europe, Africa) complementing a main 'axis' from Asia to Australia with China at the center (Deloitte Insights 2018). This imaginary could hardly be more important, as it recenters China as a benevolent and modern source of global development and wealth generation with its own institutions of finance, its own models of development, and its own rhetorics of friendship, non-intervention, and complementarity.

For Africa, the difference in these two conceptions is profound. When following the lines of the Economic 'Belt' and the Maritime Silk 'Road' China's extension of BRI to Africa is focused on the Indian Ocean ports (and additional infrastructure to serve those ports) in Tanzania, Kenya, and Djibouti, omitting the rest of the continent. The line of the 'axis' and enveloping 'wings' point to the inclusion of all of Africa as a 'west wing,' with more potential spots for investment than any other region on the globe. ${ }^{4}$ Senegal - a state that by no sleight of hand could be considered as part of the original Belt or Road - has now been reimagined as a 'key extension of the BRI' (MOFA 2018). At the same time, BRI is invoked in the opposite geographical direction, South and East across the Pacific: Ecuador and China signed a document to jointly pursue BRI in December 2018 (Mo 2018); some 5 months later Peru announced that it is set to join BRI as well (Galinda 2019). Second, it is unclear how much of BRI is simply putting the veneer of a unified plan on a range of initiatives that either were already underway or would likely have been concluded without the BRI label. For example, in July 2018 the memorandum of understanding for BRI stated that Senegal simply 'formalizes preexisting cooperation on infrastructure,' notably in a road linking the capital with Senegal's second city of Touba, and the development of an industrial park (Tiezzi 2018). A quick perusal of China's official BRI website, BRI now encompasses everything from bilateral deals for loans, official diplomatic communiques, sports tourism, the contents of BRICS summits, Confucius Institutes, Sino-African art exchange exhibits, and the full content of FOCAC. 
Thus, how much of BRI is new, how much is simply repackaged under a putatively unified program, and how much is down to investors and Chinese officials rushing to propose projects in order to pursue funding streams or demonstrate compliance with targets is at present uncertain. No one knows where the boundaries of BRI are. What is clear is that that, ambitious as it is, the BRI wrapper encompasses the earlier layers of rhetoric: insistence on national sovereignty, amity and equality (the fractal), 'win-win' based on globalized division of labor and wealth generation, and common development. And although no one knows what newer planks of BRI such as financial integration and connectivity might eventually mean for these older rhetorics, for the time being at least, participation in BRI is no impediment to the strong articulation of earlier, familiar rhetorics. For example, Ismail Omar Guelleh, President of Djibouti for nearly 20 years, has invited in Chinese investment for big infrastructure (the Doraleh Port, the Djibouti International Free Trade Zone, a water pipeline from Ethiopia, and the Djibouti-Addis rail line), taken out loans in excess of US\$1.4 billion, concluded a strategic partnership in 2017, and agreed to a Chinese naval facility that is, depending on one's perspective, either a logistics and supply station or a full-fledged naval base. Because of its location and long-term friendliness to China, Djibouti is perhaps the country in Africa most obviously tied to the BRI; if one were to find evidence of newer BRI-inflected rhetorics in Africa, Djibouti would be the place to look for it. Indeed, as befits an old friend of China, Guelleh frequently comes to China's public defense, particularly when it is accused of debt diplomacy. But instead of pointing to anything new in terms of BRI claims, Guelleh repeatedly reflects the longstanding official rhetoric of win-win cooperation and mutual benefits [sic] noting 'that the history of cooperation between China and Africa was based on win-win cooperation and mutual respect, in contrast to the defaming by some external powers' (Luo 2018).

\section{African voices and responses}

While most of Western press and think tanks are agnostic to actively critical of China's actions in Africa, it is of course much more important to get to grips with what Africans themselves think of China. And here Miles' Law - 'where you stand depends on where you sit' - is pertinent. On the whole, the political elites of African countries, particularly when they are in charge of the state, have tended to be very welcoming of China. They 
appreciate China's stress on sovereignty, its stated principles of noninterference, and its willingness to provide the critically needed transport and communications infrastructure that Western donors and businesses have either not placed in their remit (for the former) or deemed to be sufficiently profitable (for the latter). It is true that autocrats and narrow political elites (e. g. Angola, Equatorial Guinea) in resource-rich countries have continued to enrich themselves through Chinese deals, and it is little wonder that these leaders publicly support China's continued investment and presence. As but one illustrative example, as recently as January 2019, Teodoro Obiang Nguema Mbasogo, President of Equatorial Guinea and one of the most politically repressive in Africa, met with Xi Jinping's special representative and lauded China as 'an important cooperation partner' (Xinhua 2019) stating that

[Equatorial Guinea] appreciates the Chinese side's long-term and strong support and assistance, welcomes more Chinese enterprises to invest and start business in Equatorial Guinea, and is ready to further reinforce mutually beneficial cooperation with the Chinese side in jointly building the Belt and Road Initiative and implementing the eight major initiatives. The Equatorial Guinean side will continuously enhance communication and coordination with the Chinese side on international and regional affairs.

(MOFA 2019)

Given the highly repressive political environment and official cult of personality around Obiang, what most in Equatorial Guinea think of the Chinese presence, or indeed any topic, is as unknowable as what most in the PRC thought in the latter Mao years. But even in relatively open and democratic environments, African leaders and political elites are often effusive in their praise of China and consciously or otherwise mirror Chinese rhetorics. For example, when Ghanaian President Nana Akufo-Addo made a state visit to China several days ahead of the 2018 FOCAC meeting in Beijing, Chinese CCTV reported that Akufo-Addo stated:

the Ghana-China friendship forged by the two countries' older generations of leaders is unbreakable. Ghana cast its vote in support of the People's Republic of China taking its rightful seat in the UN and has been upholding the one-China principle. Ghana is willing to deepen bilateral relations, 
actively participate in the Belt and Road construction, and inject new vitality into bilateral cooperation. Marching on the road of socialism with Chinese characteristics, China plays an important role in world peace and development. China provides an important opportunity for Africa's stability and revitalization. Ghana will always be China's trustworthy friend in Africa.

(CCTV 2018)

Mirroring rhetoric such as this certainly suggests that the Ghanaian political elite either believes, or at least pretends to believe, in the vision of itself that China has in Africa: old friendship, the one-China principle, a proper role in world peace and development. Although 'win-win' based on comparative advantage is not explicitly invoked, it is implicitly present, as this official visit was accompanied by the signing of a US\$2 billion deal between the Ghanaian government and Sinohydro to swap infrastructure-building for refined bauxite - the key mineral used in producing aluminum that Ghana as yet does not have the capacity to refine. Ghanaian citizens, on the other hand, possess a range of vibrant views about China and their own government's trustworthiness in managing Chinese projects. Those resettled by the Bui Dam, a megaproject concluded between Sinohydro and the government, were promised compensation and training by a newly created Ghanaian body, the Bui Power Authority have complained in no uncertain terms about reduced farm yields, skyrocketing prices for the foodstuffs that they can no longer grow, and decreased access to forest products and fishing - to mention nothing of the gap between projected power generation and actual power generation (Yankson et al. 2018). While Ghanaians appear to be more distrustful of their own government's capacity to make decisions and follow through on the common good for the country than on China per se, there is a good deal of open criticism of a government that apes China's rhetoric in concluding deals, its lack of transparency, the terms of the deals themselves, and the poverty and youth unemployment that is omnipresent even as a minority get rich from these deals (Pilling 2018; Yen News 2018).

\section{Conclusion}

How China's rhetoric on Africa evolves, and how it will or will not take hold among a multitude of African voices remains to be seen. But, given what has and has not changed 
over the past decade, I would venture these concluding propositions. First, Chinese rhetoric will be unlikely to shift very substantially. New layers may well be added, but if the past 60 years of China-Africa interaction serves as a guide, a bedrock of amity, friendship, equality, and fractal replication, a second layer of differentiation and 'winwin,' a softening third level of 'common development' and what is at present an outer wrapper of globalized BRI will remain in place unrepudiated and ready to be drawn upon as circumstances dictate. Second, Western reporting on China and Africa may well become more nuanced and less overtly critical, but the incentives within Western reporting, its notions of what a story is, and the ways in which Western journalists are socialized and rewarded all suggest that Western press will continue to focus on the critical, the hidden costs, and the individual stories of loss and transformation that are seldom told. Unless there is dramatic regime change in the PRC, all the present indications within China are that Chinese press will become increasingly market-savvy, but will toe an ever closer domestically determined line of positive coverage on China and Africa and China and BRI. And finally, within Africa itself, the combination of diversity, growth, the spread of Internet connectivity, and ever more vibrant civil societies will convey ever wider platforms for the really important, and likely increasingly diverse and sophisticated, voices to be heard.

\section{Notes}

1 Ironically for a policy so tightly clung to for the subsequent 65 years, within 10 years the Principles proved not fit for purpose, when border clashes between China and India broke out in 1959 and a full-scale border war in 1962.

2 The creation of Confucius Institutes by a one-party state that claims to be the dictatorship of the proletariat is but the most obvious example of this kind of historically legitimating branding and the preface to Justin Yifu Lin and Yan Wang's conclusion of their influential book, 'Going Beyond Aid: Development Cooperation for Structural Transformation,' explicitly invokes quotes from Confucius and Mencius as a way to link China’s glorious past with the promising model it offers to the developing world at present (Lin and Wang 2017, 167).

3 This concern features prominently in the current discussions around China's 'debt diplomacy' and the risks inherent to highly indebted countries, many of them in Africa. 
4 A Deloitte Insights report offers apt visualization of these conceptualizations, https://www2.deloitte.com/insights/us/en/economy/asia-pacific/china-belt-and-roadinitiative.html.

\section{References}

Baidu Baike (2019) Zhongguo GDP (China's GDP), (www.baike.com/wiki/\%E4\%B8\%AD\%E5\%9B\%BDGDP), accessed 11 January 2019. Buckley, T., Nicholas, S. and Brown, M. (2018) China 2017 Review: World's Second-Biggest Economy Continues to Drive Global Trends in Energy Investment, Institute for Energy Economics and Financial Analysis, Cleveland.

CCTV (2018) China, Ghana to further enrich relations,

(www.youtube.com/watch?v=JxZL5TJg60Q), accessed 18 March 2019.

China Daily (2015) Full text: China's Second Africa policy paper, (www.chinadaily.com.cn/world/XiattendsParisclimateconference/201512/05/content_22632874.htm), accessed 11 January 2019.

Deloitte Insights (2018) Embracing the BRI ecosystem in 2018: Navigating pitfalls and seizing opportunities, (https://www2.deloitte.com/insights/us/en/economy/asia-pacific/chinabelt-and-road-initiative.html), accessed 4 November 2018.

FOCAC (Forum on China-Africa Cooperation) (2018) Beijing Declaration-Toward an even stronger China-Africa community with a shared future, (https://focacsummit.mfa.gov.cn/eng/hyqk_1/t1594324.htm), accessed 5 January 2019.

Galinda, J. (2019) Peru to join China's Belt and Road Initiative, (https://theglobalamericans.org/2019/05/just-the-facts-peru-to-join-chinas-belt-androad-initiative/), accessed 7 May 2019.

ICG (International Crisis Group) (2017) China's Foreign Policy Experiment in South Sudan, Asia Report no. 288, International Crisis Group, Brussels.

Lee, C. K. (2018) The Specter of Global China: Politics, Labor and Foreign Investment in Africa, University of Chicago Press, Chicago.

Lin, J. Y. and Wang, Y. (2017) Going Beyond Aid: Development Cooperation for Structural Transformation, Cambridge University Press, Cambridge.

Luo, J. (2018) Commentary: China-Africa win-win partnership won't be derailed by false claims, (http://english.xiongan.gov.cn/2018-09/05/c_129947658.htm), accessed 7 May 2019. 
Mao, Z. (1945) The situation and our policy after the victory in the War of Resistance against Japan, (www.marxists.org/reference//archive/mao/works/red-book/ch21.htm), accessed 8 December 2018.

Mo, J. (2018) Xi welcomes Ecuador to help build Belt, Road, (https://eng.yidaiyilu.gov.cn/qwyw/rdxw/74589.htm), accessed 16 January 2019.

MOFA (Ministry of Foreign Affairs of the People's Republic of China) (2018) Foreign Ministry spokesperson Geng Shuang's regular press conference on July 23, 2018, (www.fmprc.gov.cn/mfa_eng/xwfw_665399/s2510_665401/2511_665403/t1579567.sht ml), accessed 16 January 2019.

MOFA (Ministry of Foreign Affairs of the People’s Republic of China) (2019) Yang Jiechi meets with President Teodoro Obiang Nguema Mbasogo of Equatorial Guinea, (www.fmprc.gov.cn/mfa_eng/zxxx_662805/t1631000.shtml), accessed 20 March 2019.

Peralta, E. (2018) A new Chinese-funded railway in Kenya sparks debt-trap fears, (www.npr.org/2018/10/08/641625157/a-new-chinese-funded-railway-in-kenya-sparksdebt-trap-fears), accessed 11 May 2019.

Pilling, D. (2018) Ghana relations with China raise the emotional heat: Funds for infrastructure projects are welcome but many high-profile ventures have become headaches for Accra, (www.ft.com/content/bdb7c066-c1ad-11e8-84cd-9e601db069b8), accessed 17 March 2019.

Riskin, C. (2004) The Fall in Chinese Poverty: Issues of Measurement, Incidence and Cause, paper for the 'Keith Griffin Festschrift Conference', Amherst, 23-24 April.

State Council (2006) China's African policy, (www.gov.cn/misc/200601/12/content_156490.htm), accessed 11 January 2019.

Strauss, J. C. (2009) 'The Past in the Present: Historical and Rhetorical Lineages in China's Relations with Africa', in J. C. Strauss and M. Saavedra (eds) China and Africa: Emerging Patterns of Globalization and Development, Cambridge University Press, Cambridge, 227-245.

Strauss, J. C. (2012) 'Framing and Claiming: Contemporary Globalization and “Going Out” in China's Rhetoric towards Latin America', in J. C. Strauss and A. C. Armony (eds) From the Great Wall to the New World: China and Latin America in the 21st Century, Cambridge University Press, Cambridge, 134-156.

The Fractal Foundation (n.d.) What is a fractal? (https://fractalfoundation.org/fractivities/WhatIsaFractal-1pager.pdf), accessed 11 December 2018. 
Tiezzi, S. (2018) China's Belt and Road makes inroads in Africa, (https://thediplomat.com/2018/07/chinas-belt-and-road-makes-inroads-in-africa/), accessed 12 January 2019.

Xi, J. (2018) Full text of Chinese President Xi Jinping's speech at opening ceremony of 2018 FOCAC Beijing Summit, (www.xinhuanet.com/english/2018-09/03/c_129946189.htm), accessed 11 January 2019.

Xinhua (2019) China, Equatorial Guinea pledge to strengthen cooperation, (www.xinhuanet.com/english/2019-01/18/c_137754446.htm), accessed 20 March 2019.

Yankson, P. W. K., Asiedu, A., Owusu, K., Urban, F. and Siciliano, G. (2018) 'The Livelihood Challenges of Resettled Communities of the Bui Dam Project in Chana and the Role of Chinese Dam Builders’, Development Policy Review, 36(supplement 1), 476-494.

Yen News (2018) Ghana News Today: Ghana-China agreement - Ghanaians reaction, (www.youtube.com/watch?v=oa0qa033308), accessed 20 March 2019.

Zhou, E. (1964) The Chinese government's Eight Principles for economic aid and technical assistance to other countries, (https://digitalarchive.wilsoncenter.org/document/121560.pdf?v=7842ff83b1fa6e84a7b 0e483012dfe15), accessed 10 December 2019.

Zhu, R. (2002) Strengthen solidarity, enhance co-operation, and pursue common development, (www.china.org.cn/english/features/focac/184410.htm), accessed 7 January 2019. 